\title{
CURRENT STATE OF IMPLEMENTATION AND FUNCTIONING OF ENVIRONMENTAL MANAGEMENT SYSTEMS AT ECONOMIC ENTITIES IN UKRAINE AND THE WORLD
}

\author{
СУЧАСНИЙ СТАН УПРОВАДЖЕННЯ \\ ТА ФУНКЦІОНУВАННЯ СИСТЕМ ЕКОЛОГІЧНОГО УПРАВЛІННЯ \\ СУБ'ЄКТІВ ГОСПОДАРЮВАННЯ В УКРАЇНІ ТА СВІТІ
}

\author{
Olena V. Barabash \\ el_barabash@ukr.net \\ ORCID: 0000-0001-5206-2922
}

\author{
о. В. Барабаш, \\ канд. біол. наук, доцент
}

\section{National Transport University, Kyiv \\ Національний транспортний університет, м. Київ}

\begin{abstract}
The article analyzes the dynamics of implementation and functioning of the environmental management system for economic entities of different sectors of Ukrainian economy and examines trends in obtaining certificates of compliance with ISO 14001: 2015 in the world. It has been established that the task of achieving environmental safety and the conservation of natural resources encounters the problems related to the outdated thinking of the management of many enterprises in Ukraine and most countries of the world, their reluctance to accept and apply new environmental management tools and innovative technologies in existing industries. It is revealed that the emissions of pollutants entering the atmosphere and capable of accumulating in water bodies and soil cover from the activities of economic entities several times exceed the emissions of road transport in the period from 2016 to 2018 in Ukraine. The statistics analyzed by International Organization for Standardization since 1999 shows a steady increase in the number of enterprises certified to ISO 14001, and this trend is particularly typical for Europe and East Asia. It is revealed that the most productive activities of economic entities in the development and implementation of EMS took place during 2007-2009 and 2015-2016. It is established that the difficult political situation in Ukraine, the lack of professional environmental managers at the enterprises and in the regions, lack of interest and approaches to staff motivation, lack of economic mechanisms at the country level, which would help to achieve environmental efficiency and effectiveness of EMS in accordance with the requirements of the standards and legislation of Ukraine, the incompetence of the consulting and certification professionals, as well as the constant resistance to changes in the management of many businesses create the situation when business entities abandon the environmentally-friendly direction in their activities aimed at improving the country's environmental security in most cases.
\end{abstract}

Key words: environmental efficiency; environmental management system; economic entities; environmental security; industry.

Анотація. У статті проаналізовано динаміку впровадження та функціонування системи екологічного управління суб'єктів господарювання різних галузей економіки України та розглянуто тенденції отримання сертифікатів відповідності стандарту ISO 14001:2015 у світі. Встановлено, що для України та більшості держав світу питання екологічної безпеки та збереження власного природно-ресурсного капіталу стикається з проблемами, які пов'язані із застарілим мисленням керівництва багатьох підприємств, їхнім небажанням сприймати і застосовувати нові інструменти екологічного управління та інноваційні технології в діючі виробництва. Виявлено, що за період з 2016 по 2018 роки в Україні викиди забруднюючих речовин, які надходять в атмосферне повітря та здатні акумулюватись у водних об'єктах і грунтовому покриві, від діяльності суб'єктів господарювання в декілька разів перевищують викиди автомобільного транспорту. Проаналізовані статистичні дані International Organization for Standardization 3 1999 р. дозволяють зробити висновки про постійне збільшення кількості підприємств, сертифікованих відповідно до ISO 14001, і така тенденція є особливо характерною для країн Європи та Східної Азії. Виявлено, що протягом 2007-2009 pp. та 2015-2016 pр. спостерігалась найбільш продуктивна діяльність суб'єктів господарювання у сфері розроблення та впровадження СЕУ. Встановлено, що складна політична ситуація в Україні, брак професійних екологічних менеджерів на підприємстві та в регіонах, відсутність зацікавленості і підходів до мотивації персоналу, відсутність економічних механізмів на рівні країни, які б допомагали досягти екологічної дієвості та результативності СЕУ відповідно до вимог стандарту та законодавства України, некомпетентність спеціалістів, які надають консалтингові та сертифікаційні послуги, а також постійний опір змінам керівництва багатьох підприємств у більшості випадків спричиняють відмову суб'єктів господарювання від екологічно орієнтованого напрямку у своїй діяльності, направленого на підвищення рівня екологічної безпеки країни.

Ключові слова: екологічна дієвість; система екологічного управління; суб'єкти господарювання; екологічна безпека; галузь економіки. 


\section{ПОСТАНОВКА ЗАДАЧІ}

Швидкість темпу процесів глобалізації суттєво вплинула на природу та принципи функціонування й розвитку системи управління екологічною безпекою суб'єктів господарювання як у світі, так i в окремих країнах. Наразі багато держав розглядають упровадження системи екологічного управління (далі - СЕУ), конструктором якої виступають вимоги міжнародного стандарту ISO 14001:2015, як одне 3 найбільш ефективних рішень для задоволення зростаючої потреби в екологічно дієвому управлінні суб'єктів господарювання. Для України та більшості держав світу питання екологічної безпеки, збереження власного природно-ресурсного капіталу стикається з проблемами, які пов'язані із застарілим мисленням керівництва багатьох підприємств і небажанням сприймати та застосовувати нові інструменти екологічного управління та інноваційні технології в діючі виробництва.

Одним з ефективних інструментів суб'єктів господарювання для підвищення рівня екологічної безпеки, раціонального використання природних ресурсів для забезпечення економічного зростання $є$ впровадження системи екологічного управління. Результативна СЕУ здатна не лише підтримувати екологічно орієнтовану діяльність суб'єктів господарювання, але й отримувати суттєвий економічний ефект, фундамент якого буде закладено в розширення виробництва та географії ринків збуту.

\section{АНАЛІЗ ОСТАННІХ ДОСЛІДЖЕНЬ І ПУБЛІКАЦІЙ}

Питання екологічної безпеки підприємств розглядав Л.І. Донець [1]. Питання екологічного управління постійно розвиваються вітчизняними вченими, такими як В.Л. Акуленко [2], Т.П. Галушкіна [3]. У праці Ю.В. Кушніра [4] наголошено на перспективах застосування екологічного аудиту як дієвого інструменту контролю. Взаємозв'язок між екологічним управлінням та підвищенням конкурентоспроможності підприємства розглядають К.А. Демяненко [5], М. Портер [7], О.Г. Янковий [6]. Екологічне управління як новий ефективний метод управління внутрішнім середовищем підприємства, його впливом на довкілля та вивчення переваг у встановленні зв'язків зі стейкголдерами досліджено в працях О.В. Барабаш [8], К.В. Мазур [9], Т.В. Князєвої [10].

\section{ВІДОКРЕМЛЕННЯ НЕ ВИРІШЕНИХ РАНІШЕ ЧАСТИН ЗАГАЛЬНОЇ ПРОБЛЕМИ}

Прискорення техногенного тиску на стан природних компонентів довкілля призводить до розуміння необхідності створення екологічно дієвих та результативних природоохоронних заходів на локальному рівні, а тиск бізнес-конкурентів стає реальним поштовхом до розроблення якісно нових підходів у питаннях взаємодії підприємств 3 довкіллям. Оскільки, на нашу думку, одним із дієвих інструментів інноваційних змін для суб'єктів господарювання є впровадження СЕУ, виникає необхідність 3'ясування динаміки впровадження та сертифікації СЕУ суб'єктами господарювання різних галузей економіки та виявлення країн-лідерів у цій сфері. Такий аналіз надасть додаткові можливості для розуміння причин небажання застосовувати підприємствами та організаціями заходів, направлених на підвищення рівня екологічної безпеки, та дозволить оцінити можливості й запропонувати управлінські підходи для заохочення суб' єктів господарювання розглядати свою діяльність через призму можливостей зменшення негативного впливу на стан навколишнього середовища.

Мета дослідження - стан впровадження систем екологічного управління суб'єктів господарювання 3 дотриманням відповідності вимог ДСТУ ISO 14001:2015.

\section{МЕТОДИ ДОСЛІДЖЕННЯ}

$\mathrm{У}$ роботі виконано комплексний системний аналіз, який включає узагальнення статистичних даних International Organization for Standardization щодо динаміки впровадження та функціонування систем екологічного управління суб'єктів господарювання.

Об'єкт дослідження - процеси розроблення та впровадження систем екологічного управління суб'єктів господарювання в Україні та світі.

Предмет дослідження - вплив впровадження та функціонування систем екологічного управління суб'єктів господарювання на покращення їх екологічної дієвості та стан екологічної безпеки в Україні та світі.

\section{ОСНОВНИЙ МАТЕРІАЛ}

Поняття «система екологічного управління» традиційно поєднують і розглядають в серії стандартів ISO 14000 , які були розроблені Міжнародною організацією зі стандартизації - International Organization for Standardization (ISO) [11], яка була створена у 1946 p. на основі двох організацій: International Federation of the National Standardizing Associations та United Nations Standards Coordinating Committee. Завдання ISO: 1) сприяння розвитку стандартизації та суміжних видів діяльності у світі з метою забезпечення міжнародного обміну товарами і послугами; 2) сприяння розвитку співробітництва в інтелектуальній, науково-технічній та економічній сферах. Оскільки ISO $\epsilon$ незалежною неурядовою міжнародною організацією, а в іiї діяльність залучені національні органи зі стандартизації та експерти, які діляться кращими практиками, саме тому добровільні, засновані на консенсусі стандарти сприяють упровадженню інновацій та мають на меті подолання глобальних викликів. Кожен рік експерти організації проводять моніторинг динаміки впровадження стандартів у світі, зокрема ISO 14001:2015 «Environmental management systems Requirements with guidance for use». 


\section{ТЕХНОЛОГІЇ ЗАХИСТУ НАВКОЛИШНЬОГО СЕРЕДОВИЩА №2 2019}

\section{ОБГОВОРЕННЯ ОТРИМАНИХ РЕЗУЛЬТАТІВ}

Основними стратегічними цілями України є зменшення негативного впливу процесів урбанізації на довкілля, припинення його руйнування та збереження у межах міст шляхом стимулювання оновлення зношених основних фондів промислової і транспортної інфраструктури та об'єктів житлово-комунального господарства через стимулювання їх до впровадження більш екологічно чистого, ресурсоефективного виробництва та екологічних інновацій [12].

За статистичними даними, отриманими за період з 2016 по 2018 роки, в Україні викиди забруднюючих речовин від стаціонарних джерел у декілька разів перевищують викиди, які надходять в атмосферне повітря та здатні акумулюватись у водних об'єктах і грунтовому покриві (рис. 1).

Токсичні продукти, які виділяються в атмосферне повітря внаслідок діяльності суб'єктів господарювання, у порівнянні з викидами автомобільного транспорту під час різних режимів руху та в залежності від типу двигуна $€$ досить різноманітними, зокрема діоксид сірки, аміаку, тверді частинки, а кількість їх різна в залежності від виду діяльності суб'єкта господарювання (рис. 2).
Для покращення стану довкілля в Україні передбачено ряд заходів для зменшення забруднення атмосферного повітря, грунтового покриву, водних об'єктів та їх ресурсів, а також запроваджено зміни в державному управлінні через введення екологічних норм та стандартів [12]. Вимірними показниками для оцінки ефективності реалізації державної екологічної політики визначено 35 індикаторів, які стануть своєрідним контролем у створенні нової моделі громадянського суспільства, заснованої на соціоекологоекономічному зростанні. Для реалізації екологічної політики України необхідно передусім забезпечити умови для ефективного впровадження суб'єктами господарювання систем екологічного управління, заснованих на постійному поліпшенні екологічної дієвості та результативності відповідно до вимог ДСТУ ISO 14001:2015, що може бути впроваджений у бізнес будь-якого масштабу. Для досягнення екологічної дієвості керівництво підприємств повинно враховувати необхідність застосування: 1) управлінських підходів, направлених на екологічну мотивацію; 2) процедур систематичної оцінки стану навколишнього середовища, що охоплюють специфіку галузі, в який працює підприємство; 3) стратегічного підходу, на-

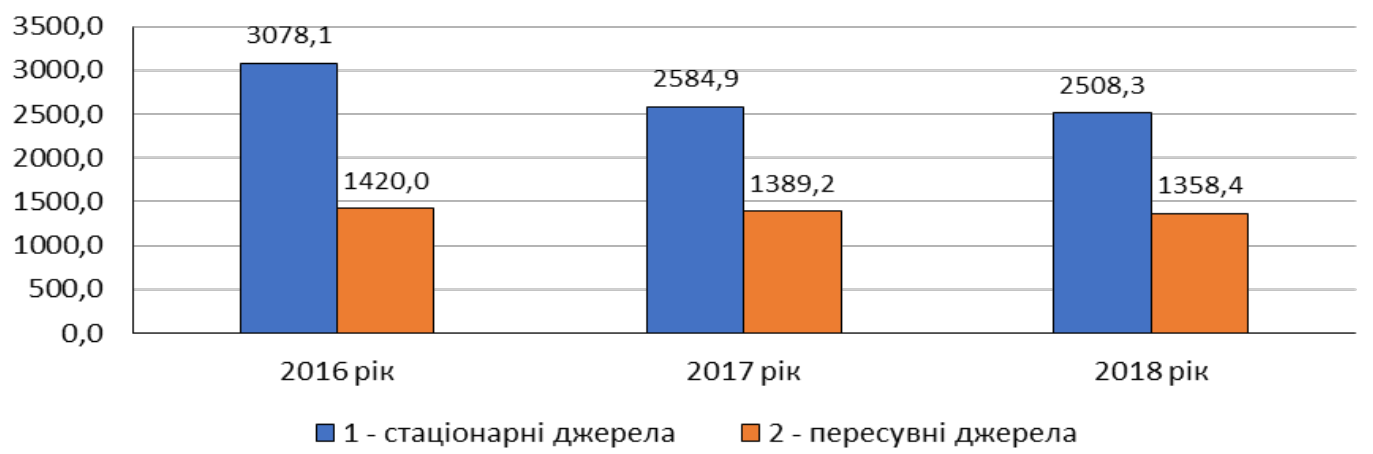

Рис. 1. Викиди забруднюючих речовин від діяльності стаціонарних та пересувних джерел

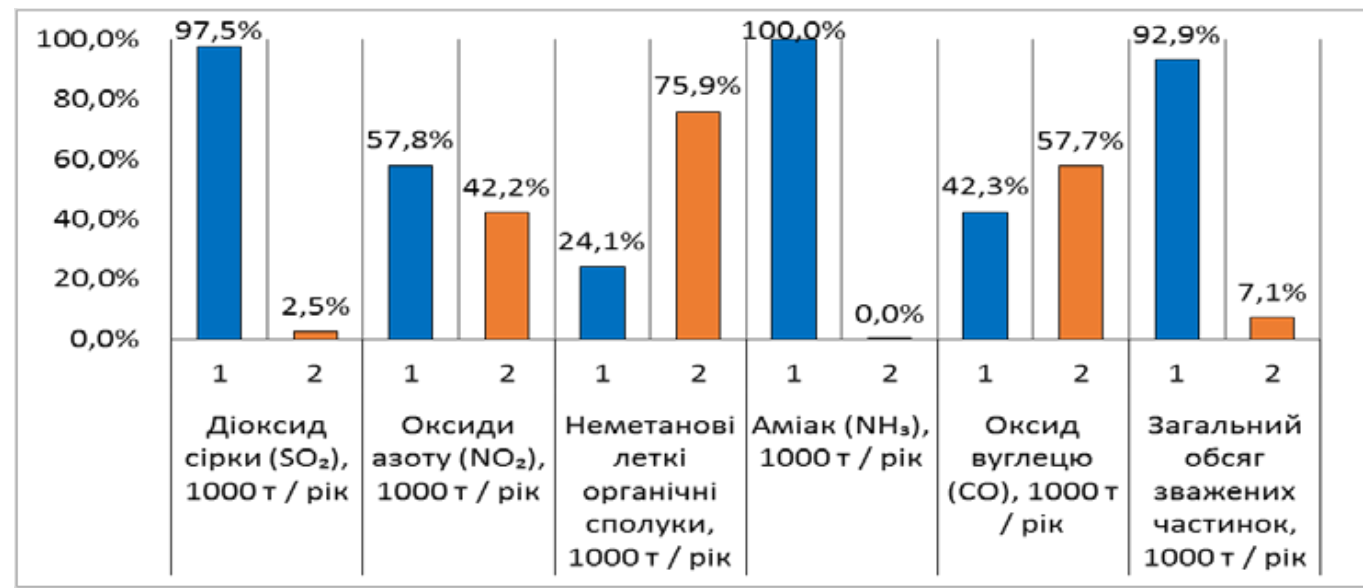

Рис. 2. Частка викидів токсичних сполук у довкілля від стаціонарних та пересувних джерел забруднення 
правленого на довгострокові перспективи в досягненні суб'єктом господарювання екологічної дієвості й результативності СЕУ, що впроваджена.

Починаючи з 1999 р., у світі спостерігається постійне збільшення кількості підприємств, сертифікованих на ISO 14001, особливо це стосується країн Свропи та Східної Азії (рис. 3).

За даними ISO, протягом 2007-2009 pр. та 20152016 рр. спостерігалась найбільш активна діяльність суб'єктів господарювання у розробленні й впровадженні СЕУ (рис. 4).

Спад активності у впровадженні ISO 14001 та зменшення кількості сертифікованих підприємств спостерігалися після 2016 року, що пов'язано як із необхідністю переходу на нову версію стандарту 2015 року, браком коштів, світовою економічною кризою, так із відсутністю або недостатньою розробленістю і баченням керівництвом підприємств стратегічних цілей у досягненні екологічної дієвості. Незважаючи на це, ISO 14001:2015 має досить великий попит серед суб'єктів господарювання різних галузей економіки в усьому світі (рис. 5).
За даними рис. 5 можна стверджувати, що найбільш затребуваними є системи екологічного управління у сфері будівельної галузі.

В Україні впровадження ДСТУ ISO 14001:2015 відбувається досить повільно, як загалом у державі (рис. 6), так і в окремих секторах економіки (рис. 7).

За даними організації ISO встановлено, що більшість суб'єктів господарювання в Україні не готові до змін для покращення стану довкілля. Така тенденція прослідковується не лише у відсутності даних щодо реєстрації кількості підприємств, які впровадили СЕУ, але й у наданні International Organization for Standardization актуальних показників. Окрім того, для міжнародної спільноти недоступні дані про кількість суб'єктів господарювання за секторами економіки, які в Україні перейшли на нову версію ДСТУ ISO 14001:2015 та отримали сертифікат відповідності.

За секторами економіки в Україні спостерігається повна невизначеність щодо галузей, які впровадили та підтримують систему екологічного управління. Тому дані, які оприлюднила International Organization for Standardization, є доволі розмитими і не показують

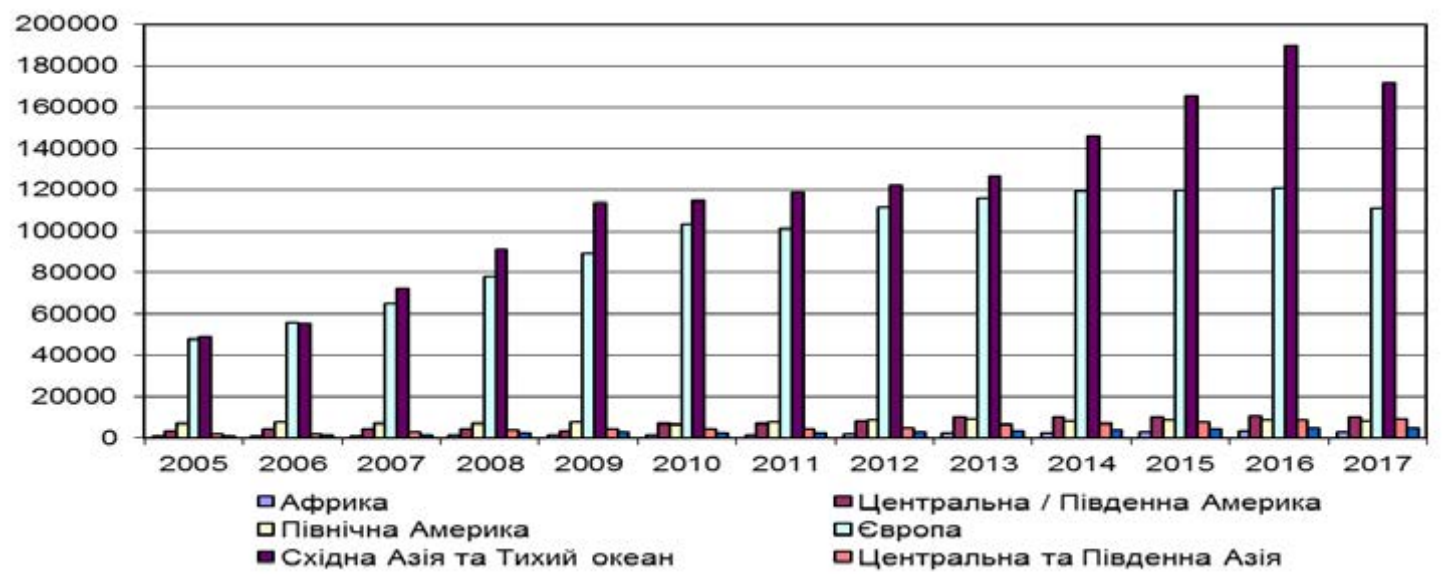

Рис. 3. Впровадження ISO 14001

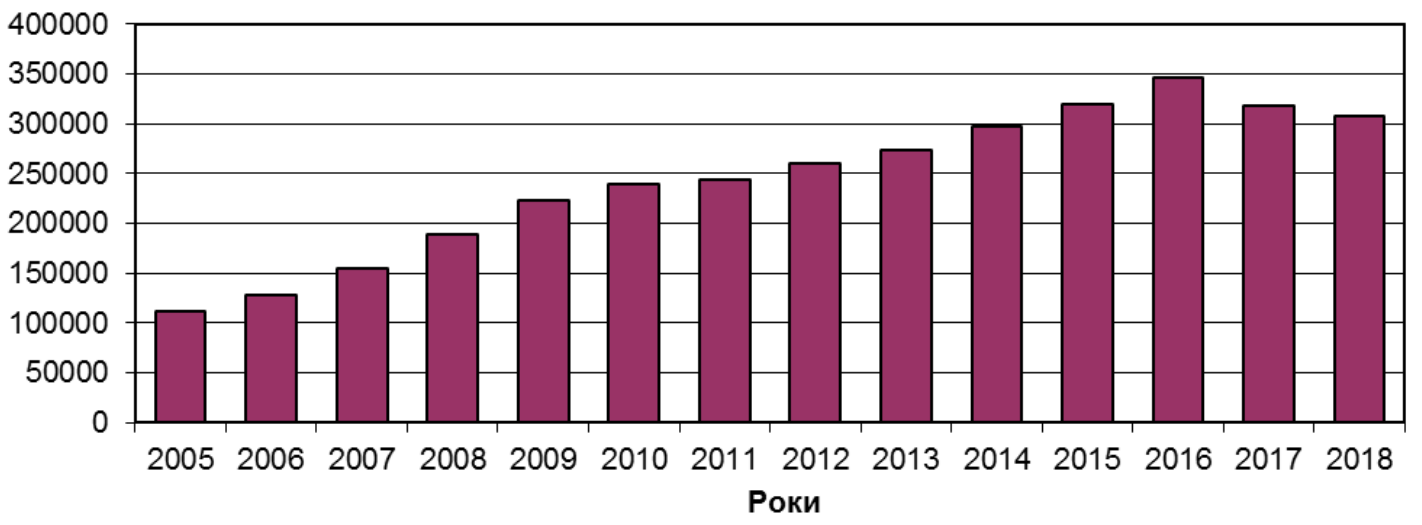

Рис. 4. Тенденції для впровадження ISO у світі 


\section{ТЕХНОЛОГІЇ ЗАХИСТУ НАВКОЛИШНЬОГО СЕРЕДОВИЩА № 2 व 2019}

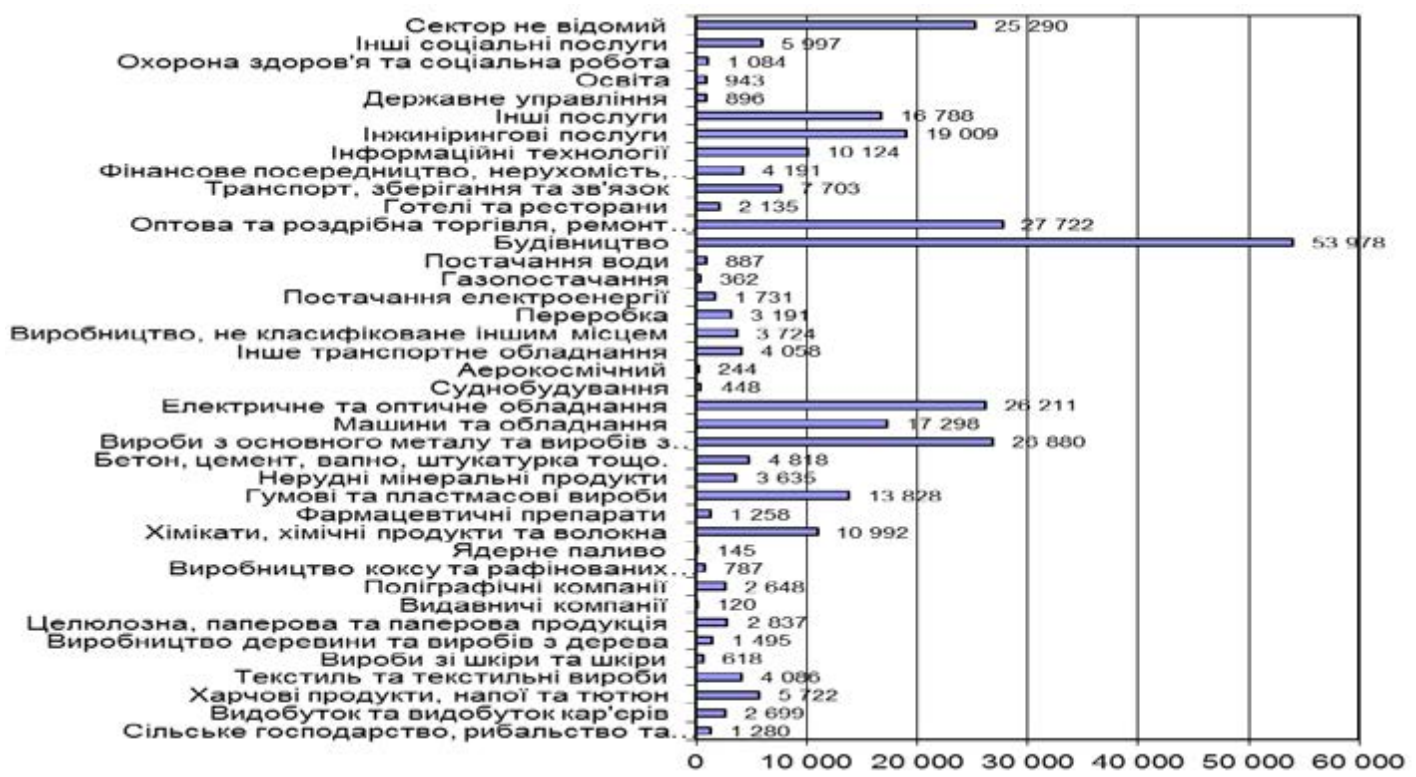

Рис. 5. Впровадження суб' єктами господарювання ISO 14001 у світі в різних галузях економіки

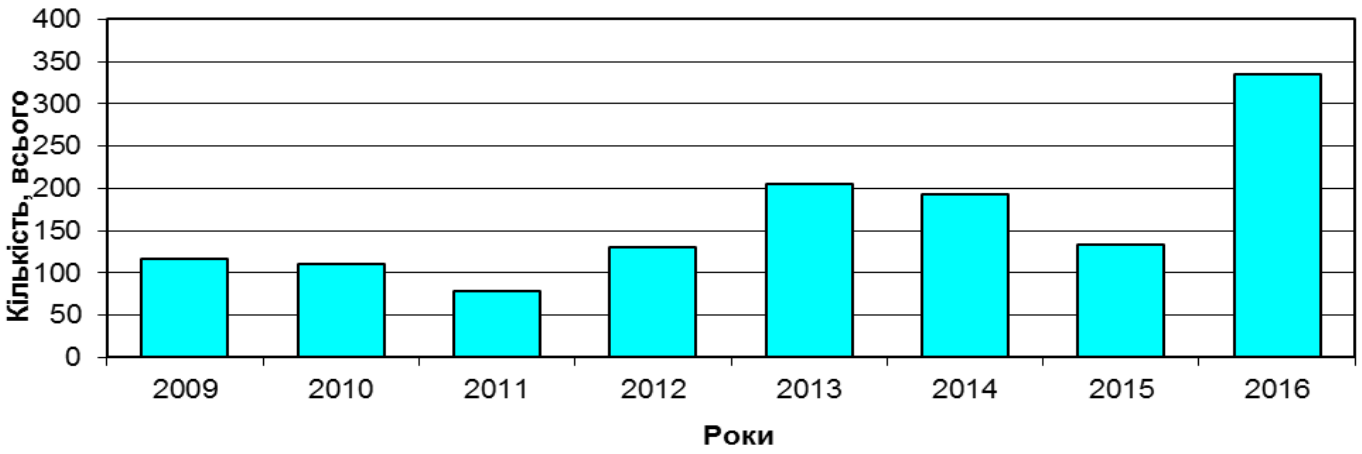

Рис. 6. Кількість підприємств в Україні, сертифікованих на ДСТУ ISO 14001:2015

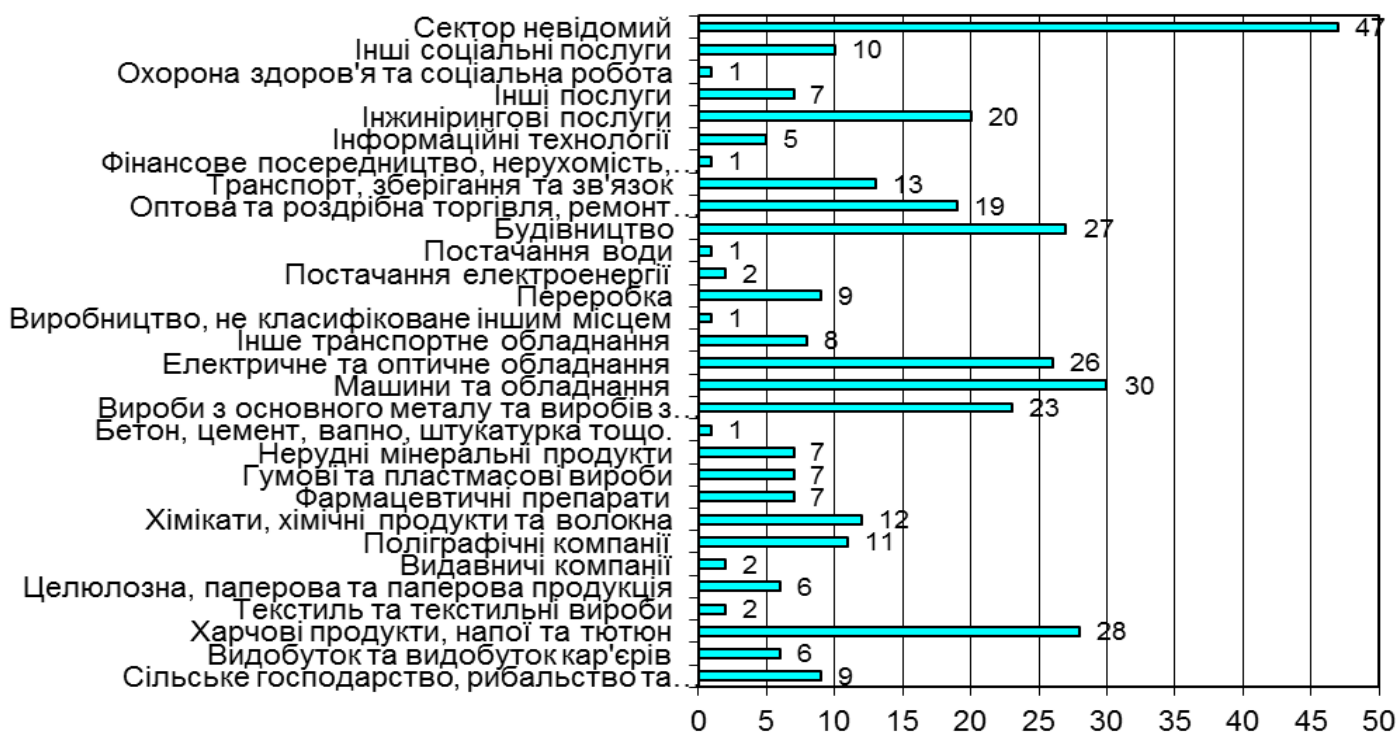

Рис. 7. Впровадження СЕУ за галузями в Україні 
реальної картини через наявність СЕУ в підприємств «невідомого сектору» економічної діяльності.

\section{ВИСНОВКИ}

Встановлено, що складна політична ситуація в Україні, брак професійних екологічних менеджерів на підприємстві та в регіонах, відсутність зацікавленості й підходів до мотивації персоналу, відсутність економічних механізмів на рівні країни, які б допо- магали досягти екологічної дієвості СЕУ відповідно до вимог стандарту і законодавства України, некомпетентність спеціалістів, які надають консалтингові та сертифікаційні послуги, а також постійний опір змінам у більшості випадків спричинюють відмову суб'єктів господарювання від екологічно орієнтованого напрямку у своїй діяльності, направленого на підвищення рівня екологічної безпеки країни.

\section{REFERENCES}

[1] Donets' L.I., Prokopenko Ye.Yu. (2006). Ekolohichna bezpeka v koordynatakh svitovoho rozvytku. Visnyk Khmel'nyts'koho natsional'noho universytetu. 6 (1). 151-154. [in Ukraine]

[2] Akulenko V.L., Mamchuk I.V. (2009). Ekolohichnyy menedzhment v konteksti zabezpechennya ekolohichnoyi bezpeky pidpryyemstva. Visnyk Khmel'nyts'koho natsional'noho universytetu. 5 (1). 21-26. [in Ukraine]

[3] Halushkina T.P. (2000). Ékonomycheskye ynstrumenty ékolohycheskoho menedzhmenta: teoryya y praktyka. Odessa: YPRyÉÉY NAN Ukrayny, 280. [in Ukraine]

[4] Kushnir Yu.V. (2005). Perspektyvy vprovadzhennya systemy ekolohichnoho audytu na promyslovykh pidpryyemstvakh. Naukovyy visnyk NLHU. 15. 251-254. [in Ukraine]

[5] Demyanenko K. A. (2015). Sutnist' ta skladovi systemy ekolohichnoho menedzhmentu. Yevropeys'ki perspektyvy. 6. 47-52. [in Ukraine]

[6] Yankovyy O. H. (2013). Konkurentospromozhnist' pidpryyemstva: otsinka rivnya ta napryamy pidvyshchennya. Odesa: Atlant. 470. [in Ukraine]

[7] Porter M. (1998). Stratehiya konkurentsiyi: Metodyka analizu haluzey i diyal'nosti konkurentiv. Kyiv:Osnovy. 390.[in USA]

[8] Barabash O. V. (2018). Efektyvnist' systemy ekolohichnoho menedzhmentu yak indykator ekolohichnoyi bezpeky ahlomeratsiy. Ekolohichni nauky: naukovo-praktychnyy zhurnal. 4 (23). 14-19. [in Ukraine]

[9] Mazur K. V. (2016). Ekolohichnyy menedzhment yak novyy efektyvnyy metod upravlinnya vyrobnytstvom. Molodyy vchenyy. 2. 60-63. [in Ukraine]

[10] Knyazyeva T. V. (2014). Rozvytok systemy ekolohichnoho menedzhmentu na pidpryyemstvi: osnovni teoretychni polozhennya. Teoretychni i praktychni aspekty ekonomiky ta intelektual'noyi vlasnosti. 1 (1). 391-396. [in Ukraine]

[11] ISO - International Organization for Standardization: URL: https://www.iso.org/ru/home.html

[12] Zakon Ukrayiny «Pro Osnovni zasady (stratehiyu) derzhavnoyi ekolohichnoyi polityky Ukrayiny na period do 2030 roku» (VVR Ukrayiny, vid 28 lyutoho 2019 roku № 2697-VIII). URL: https://zakon.rada.gov.ua/laws/show/2818-17 [in Ukraine].

\section{СПИСОК ВИКОРИСТАНОЇ ЛІТЕРАТУРИ}

[1] Донець, Л. І., Прокопенко, С. Ю. (2006) Екологічна безпека в координатах світового розвитку. Вісник Хмельницького національного університету. № 6 (1). С. 151-154.

[2] Акуленко, В. Л., Мамчук, І. В. (2009). Екологічний менеджмент в контексті забезпечення екологічної безпеки підприємства. Вісник Хмельницького національного університету. № 5 (1). С. 21-26.

[3] Галушкіна, Т. П. (2000) Экономические инструменты экологического менеджмента: теория и практика. Одесса : ИПРиЭЭИ НАН Украины. 280 с.

[4] Кушнір, Ю. В. (2005) Перспективи впровадження системи екологічного аудиту на промислових підприємствах. Науковий вісник НЛГУ. №. 15. С. 251-254.

[5] Демяненко, К. А. (2015) Сутність та складові системи екологічного менеджменту. Свропейські перспективи. № 6. С. 47-52.

[6] Янковий, О. Г. (2013) Конкурентоспроможність підприємства: оцінка рівня та напрями підвищення. Одеса : Атлант. $470 \mathrm{c.}$

[7] Портер, М. (1998) Стратегія конкуренції: Методика аналізу галузей і діяльності конкурентів. Київ : Основи, 1998. $390 \mathrm{c}$.

[8] Барабаш, О.В.(2018) Ефективність системи екологічного менеджменту як індикатор екологічної безпеки агломерацій. Екологічні науки: науково-практичний журнал. № 4 (23). С. 14-19.

[9] Мазур, К. В. (2016) Екологічний менеджмент як новий ефективний метод управління виробництвом. Молодий вчений. № 2. С. 60-63.

[10] Князєва, Т. В. (2014) Розвиток системи екологічного менеджменту на підприємстві: основні теоретичні положення. Теоретичні і практичні аспекти економіки та інтелектуальної власності. № 1 (1). С. 391-396.

[11] ISO - International Organization for Standardization. URL: https://www.iso.org/ru/home.html

[12] Закон України «Про Основні засади (стратегію) державної екологічної політики України на період до 2030 року» (ВВР України, від 28 лютого 2019 року № 2697-VIII). URL: https://zakon.rada.gov.ua/laws/show/2818-17 